\title{
Television's Self-Regulating Sexualities and Genders, or the Stories about "Taking Risks"
}

\section{Brady, Anita, et al. Mediating Sexual Citizenship: Neoliberal Subjectivities in Television Culture. Routledge, 2018. pp. 169.}

Mediating Sexual Citizenship: Neoliberal Subjectivities in Television Culture is a collection of case studies dealing with neoliberal framing of gendered and sexual contemporary citizenship. The authors situate their analysis in the current landscape of television production as well as in the scholarly work dealing with the issues of gender and sexuality in television culture and otherwise. As they point out in the introduction of the book, contemporary television of the 21st century must be understood through the lens of technological changes in television transformation, which created divergent ways of constructing narratives, distributing them across various platforms, and finally, making space for new ways of consuming television content. Transformation by divergence has not become evident solely in the technological extent of creating content, but it also affected the ways of storytelling. Television narratives are no longer bound to formulas used in network television, intended for industrial-like production and mass viewership. This opened up space for experimental ways of constructing storytelling as well as engaging in more complicated representations, especially those concerning gender and sexuality. In the introductory note of the book, the authors are aiming for perspective of television as a site of cultural discourse but also as a highly commercial product.

Conceiving television as both a cultural and commercial product enables the authors to explore its connection to neoliberalism in two ways. Neoliberal ideologies are, above all, visible in the transformation of television system as it became dispersed through various platforms and is now tailored for individualized consuming practices. Neoliberal framing is then also evident through 
representation in television narratives, mainly through the ideologies of self-building and selfgoverning. Finally, such neoliberal framing of television, both through material and narrative aspects, intersects with representations of gender and sexuality. Here, the authors rely on the theoretical perspectives which emphasize the notion that neoliberal ideologies are always already gendered and are as such reproduced through different television archetypes. This analysis follows the understanding of neoliberalism as a mode of governance that emphasizes free market and trade, as well as the rise of individuality through self-management and self-building of skills that would ultimately receive its worth in the market and provide an individual with extended freedom as well as economic and social well-being. As they claim, their analysis leans on the body of scholarship which considers television to enact and privilege "privatized and individualized models of citizenship" (10).

The authors' choice of material in this case study is relevant and constructive for the analysis. The materials presented in case studies vary in genre and format as analysis focuses on series' narratives as well as reality format, while also including the genres of drama, comedy, crime, etc. Although the genre borders in contemporary television landscape are not only blurred but the majority of programs insist on fusing different genres under one title, different genre formulas also make for different tropes in discursive logic in the representation of gendered and sexual citizen, which the authors recognize in detail. The titles chosen for this work also largely fall under the category of what has been perceived as "quality television" and are often branded as "risk-taking" television projects. Once again, it is acknowledged that such projects can be seen as evidence of neoliberal framing within the practice of television industry. Also, the titles used for this work enact discourses already recognized in the body of scholarly work on television representation that the authors lean on. For example, representations of dysfunctional families struggling to maintain the order of the nuclear family under great economic demands are found in Weeds (2005-2012) and Breaking Bad (2008-2013). The mechanisms of constructing hegemonic masculinity through selfreliance and re-invention are discussed through the narrative of Friday Night Lights (2006-2011). Reality format of the I Am Cait (2015) is built around the manufactured drama of Caitlyn Jenner, attempting to build the transgender self around political labor, which illuminates the economic underpinnings of transgender politics. 
The authors divided the book into five chapters, related to current issues in understanding gender and sexuality in popular culture. Chapters follow the similar outline of analysis. We are given a short introduction to the material used and how it is distributed through viewing platforms. The authors then take up narrative moments and characters relevant to the analysis. The scholarly aim of this book is perhaps best realized in the chapter dealing with gay masculinities. Here, the authors focus on three television shows: Queer Eye (2003-2007), Modern Family (2009-), and Looking (2014-2016).

All of the shows are situated in the context of the so-called "pink economy discourse" (54), explaining how gay subjectivities are bound to consumerism and the neoliberal idea of self-building and perfecting. Queer Eye makes this evident as it relies on the popular culture myth of a fashionable gay man who is socially crafted to be a holder of expertise in clothing, culture, design, and body care. Queer Eye thus constructs the gay subject as a contemporary gay man who has "an innately privileged access to knowledge that characterizes discerning modes of consumption" (55). As the authors point out, this is done to the extent in which consumer desire is situated at the center of gay subjectivity, almost entirely replacing sexual desire. It is explained in detail how the show enacts the myth of the feminized and knowledgeable gay man to define consumptive practices and strategies of self-management as needed for fulfilling the idea of satisfactory citizenship. Embedding consumption practices in gay subjectivities continues to be a topic when the authors deal with mockumentary sitcom Modern Family. Here, we are given the context of the mainstream liberal gay politics that is mostly focused on marriage equality. In such a discourse, the intimate and domestic life of gay partners is constructed as one with the potential to reflect and successfully imitate the life of heterosexual partners. Situated within the strong line of conflictresolution family sitcoms of American television, Modern Family's gay couple (Mitch and Cam) is depoliticized and desexualized. As partners, they are centered in the domestic life that is built around attempting to achieve the heteronormative fantasy of middle class family, including all of its pertaining consumptive habits. Looking represents neoliberal sexual politics in a similar way. Although the characters of the series are not desexualized as they are in Modern Family, their sexual practices are represented as "perpetual adolescence" (71), which ends only when a gay man accepts marriage and domesticity as a way to a fulfilled citizenship. 
Although the authors claim that relating public discourse to the analyzed television material is one of the aims of the book, this is not entirely evident in all of the chapters presented. The book would benefit from further analysis on the media discourse created around these television projects, as these might further illuminate the practices of neoliberal framing of the content. Relating content to its further signifying practices in public is perhaps best evident in the case study of Breaking Bad and the constructions of hegemonic masculinity. It could be sad that the character of Walter White in many ways surpassed the relevance of the series. The character still serves as an embodiment of the anti-hero morally struggling to manage under neoliberal conditions of economic crisis. As is explained in detail in this chapter, the construction of hegemonic masculinity arises, in great part, from these economic conditions. Regardless of the moral complexity of the character, his popularity remains bound to the traits of hegemonic masculinity. This might signal that public discourse, especially that of "quality television," often remains uncritical of the content and further reproduces neoliberal subjectivities of television culture. Of course, this collection of case studies would then require a much broader research scope and theoretical discussion than is presented in the book. Nevertheless, the book fully achieves its aim as it effectively demonstrates how television functions as a site of the production of gendered and sexual citizenship by enacting neoliberalism as "hegemonically articulated series of discursive logics" (167). In this format, the book acts successfully as reading material for a range of courses dealing with gender and sexuality, particularly those elaborating on the shifting constructions of citizenship under neoliberal conditions.

\section{(c) (i) (9)}

Creative Commons Attribution-NonCommercial-NoDerivatives 4.0 International License 